\title{
A NOVEL AND TWO LETTERS
}

\author{
By GEORGE ARMS
}

IN RECEN'T YEARS the Library has added to its collection of material by William Dean Howells until now it owns nearly every title this great American ever published. It has also acquired some sixty or seventy unpublished letters which Howells wrote between ${ }_{1} 859$ and the end of his life. Dr. Arms, recently appointed a member of the Department of English at the University of New Mexico, has in the following account told the story behind one of these letters. We are indebted to Miss Mildred Howells, who has graciously allowed us to print the letters in this article, and to $M r . W . E$. Louttit, Jr., the owner of one of the letters.

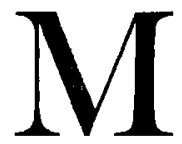

OST of the letters in the Howells collection at Rutgers contribute to an understanding of Howells as a literary craftsman, some more directly than others. A splendid example is a letter that seeks information to be used in writing $A$ Woman's Reason. In order for the reader to see the significance of the letter, and of another which was discovered through inquiry about it, a brief description of the novel will prove helpful.

At the opening of the story, Helen Harkness, after having danced her way with a class through Harvard, had rejected the suit of a naval officer, Robert Fenton. He naïvely believed her rejection final, and accepted a long-term appointment to the naval station in Hong Kong. But within a week of his departure, Helen's father died, while the insecure estate that had survived the prosperous days of the India trade was rendered even less liquid by the hard times of 1873 . Of it a mere five thousand dollars was saved. Helen, having renewed her engagement with Robert by letter, spurned the help proffered by her friends the Butlers, and determined to support herself until her fiancé could return.

Emotionally and technically, she had no preparation for her new life. "She was, as the sum of it, merely and entirely a lady," writes Howells, "the most charming thing in the world, and as regards anything but a lady's destiny the most helpless." " First she tried vase decoration; but when her vases were sold, she was indignant that the shop-keeper should have used her name in bringing them to his cus-

${ }^{1}$ A Woman's Reason (Boston, I883), p. 137 . 
tomer's notice. She then undertook a job tinting photographs; but the tawdriness of the task revolted her and she was glad when she received no more commissions. Her single book review-for she next turned to writing - gained acceptance only through the friendly compassion of an editor. Yet her final venture was more rewarding. After her failure as a fashionable milliner, she re-established her millinery shop in the home of her former servant, where she secured enough custom to support herself - and to lose her health. Even so, the prosperity was not lasting.

These several economic enterprises did not crowd out emotional crises. When she learned that her capital of five thousand dollars had been saved by the fraud of an auctioneer, she returned it to the purchaser of her home-who astonished her by a proposal. A Lord Rainford, introduced by the Butlers, also courted her. She rejected him too, though by this time she believed that Robert had been lost at sea.

The reader of the novel knows better. Released by his superior officer, Robert had returned almost immediately from Hong Kong. But the liner he had sailed on had been disabled, he had transferred to a clipper ship in mid-Pacific, the ship had been wrecked, and Robert, after heroically refusing a chance at rescue, had spent two years with a single companion on an atoll. Discovered by a whaler, he returned to Helen (who was in a fair way to achieve financial independence as a photographer's receptionist). And so: "They were married, and went to live in a little house in a retired street of Old Cambridge. ..." Later Robert received an appointment as commandant of the Narragansett Navy Yard.

In I878, the year when we first hear of $A$ Woman's Reason, Howells was still editor of the Atlantic Monthly. He had published three novels, and a fourth, The Lady of the Aroostook, was to begin its appearance in the November number of his magazine. A letter now owned by Mr. W. E. Louttit, Jr., of Providence, indicates that a fifth novel was already in the making:

Dear Mr. Collier:

February 25, I 878 .

I'm sorry to return this. Try something else more in the vein of Recording.

More autobiogs. soon. Marmontel, and then Cellini. 
-I am sending away (in a story) a young naval officer who is to come back in about three years, and marry a young lady. Where should he go? Is there a U.S. naval station at China or Japan? Can an officer who wants to go on a long cruise exchange very suddenly with one who doesn't want to go, and go in his place?

Yours truly

\section{W. D. Howells. ${ }^{2}$}

The "Recording" referred to in the letter was a poem which had appeared in the February, 1878, Atlantic Monthly. Howells had evidently learned that his contributor was in the Navy and that he knew a good deal about the Pacific. Collier seems to have assented to Howells's plan for securing the absence of the novel's hero. ${ }^{3}$ But technical considerations gave rise to further questions. These appear in the letter, now in the Howells collection of the Rutgers University Library, which is the focal point of this article:

My dear Mr. Collier:

May 4, I 878.

I beg to turn to you again for use of your naval knowledge.

You may remember that I consulted you about sending off a young hero of mine, (of the U.S.N.) to the China station. Having got him safely there, I now wish to have him try to get back to the young lady whom the sudden death of her father has left more than commonly forlorn. So I want to ask:

I. How are letters best addressed to naval officers? Through the Navy Department?

II. How would an officer telegraph from China? That is, what is the nearest cable-station?

${ }^{2} \mathrm{I}$ am indebted to Mr. F. C. Marston, Jr., of Brown University, for calling this letter to my attention when $I$ was trying to identify the Collier of the Rutgers letters. My own remarks about Thomas Stephens Collier are derived from Mr. Marston's letter in American Notes and Queries, March, I 944, III, I 8 5- 86.

The Marmontel essay, one of a series of introductions to autobiographies, appeared in the Atlantic, March, I878. The other essay appeared neither in the magazine nor in a book.

${ }^{3} A$ Woman's Reason, p. I 9. 
III. How would he go about to get leave of absence? Could he get it in some exigencies from his superior officer, or from the nearest U. S. Minister, or must he wait for leave from Washington?

IV. What are the chances by which an officer wishing to return and having interest with his superior could get himself sent home on business of the service? Or are there no chances?

V. Suppose the young man to have started home, how would he come? Are there steamers for California direct from China?

VI. What would be a good accident by which I could delay the steamer, or make her put back; and would it be imaginable that the young man should try to push on by sailing vessel?

VII. On what island, or little visited coast could I have him wrecked so as to delay his arrival in America for [sic] a year or two?

You see I have asked you some hard questions; but I rely on your kindness.

Yours sincerely

W. D. Howells.

Each of the questions except the second is relevant to the story as we now have it, ${ }^{4}$ and the letter thus indicates that at least as far as the Fenton-Hong Kong parts of the novel are concerned, Howells had already outlined his plot. Thus it is curious that the novel was not to be finished until I 883 , the year of its periodical and book appearance. ${ }^{5}$

4 The final treatment of the problems was as follows: I. Letters were addressed through the Navy Department (see $A$ Woman's Reason, pp. I 16, I5o). II. Robert did not cable from China, but Helen considered cabling to him (pp. 229, 240, 213). Though the possibility of her doing this is accepted as a fact in the novel, no cable connection seems to have been effected at the time. III. Robert, unable through the circumstances of appointment to request leave, was returned by his superior officer as the bearer of despatches (pp. 217, 225). IV. The repatriation was arranged by the doctor to save the life of Robert, suffering from acute nostalgia. V. Robert returned on a steamer bound for San Francisco, via Yokohama (pp. 225 226). VI. After the steamer's shaft was broken, he continued on a clipper (pp. 228-23I). VII. The first reef was only tenable at low tide. The final island is an unnamed atoll, on which the two survivors lived about eighteen months (pp. 237, 246, 435, et passim).

${ }^{5}$ For the full story of its vicissitudes between 1878 and 1883 , see Life in Letters of William Dean Howells (Garden City, 1928), I, 255, 319, 324, 329; Life and Letters of Sir Edmund Gosse (New York, 1931), p. 155; an article by Gosse in Living Age, July 10, 1920, CCCVI, 99 . 
EDTORIAL OFFICE OF

JHE -Atrantic Monthly.

Wistunor squan,
вoston.

Hy lian the balliar:

of frg to harn to you agane. fis are of your paval tenestedge.

Yhe nay smonuber that I

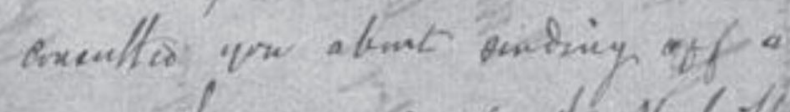

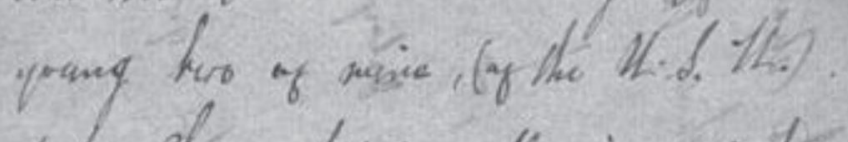
Tothe Plane staterie. Akuving got hime

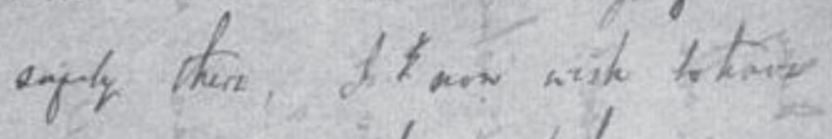
him his to get hack tothe youry

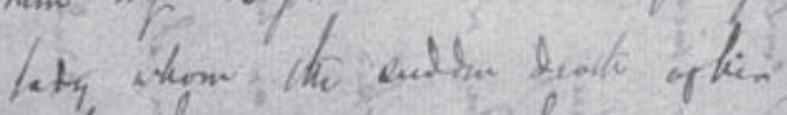

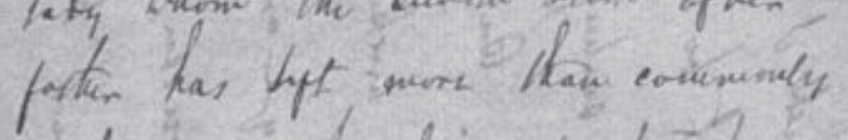
fulore do of waint lo ask.

I. Afor are thin bus atrume wherat ntiase st Srangh the thery Departhunt?

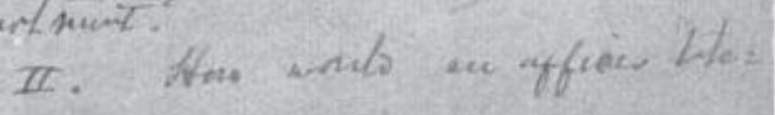


There were reasons for the long delay. Although Howells was busy during these five years, he was largely busy with other novels. He had given up his editorship of the Atlantic in I88I partly because he wanted more time for writing. But this novel posed a special problem. Wrecking a hero on a coral island was not quite in the manner of the novelist who had professed an exclusive interest in everyday life. Not infrequently in the book itself we find him apologizing for his frequent use of coincidence and fantastic adventure. ${ }^{6}$ In the novels written between 1878 and I 883 he follows a path of no high romance, but that of even more painstaking realism of the commonplace. Nor had he merely written such a book as $A$ Modern Instance (published I882). In the critical paper on James he had defined the "new school" and declared himself a member: "... it studies human nature much more in its wonted aspects, and finds its ethical and dramatic values in the operation of lighter but not less vital motives. The moving accident is certainly not its trade; and it prefers to avoid all manner of dire catastrophes." Yet while writing in this vein he was refurbishing a tale of shipwreck on an atoll.

Of this conflict between the novel and his beliefs he may have been conscious when he wrote: "I find it as I go on a most difficult and delicate thing to handle, but I hope to make it justify itself." ${ }^{8}$ The result did not justify the expectation. A Woman's Reason cannot qualify with the best of Howells's novels, and a good many critics would group it with his worst, if not at the very bottom of the list. The novel does have significance in marking a new, though not successful, attempt to develop his rather placid stories of the I870's into somewhat more tempestuous ones.

When $A$ Woman's Reason is considered in this light, the Rutgers letter assumes importance. It shows Howells's painstaking attempt to be accurate even when fantastic. What matters more, it helps to establish how much of $A$ Woman's Reason had been written five years before its completion-a fact that explains some of the story's weakness.

${ }^{6} A$ Woman's Reason, pp. 407, 421-422, 446, 453.

${ }^{7}$ Century Magazine, November, 1882 , as quoted in Life in Letters, I, 327.

${ }^{8}$ Life in Letters, I, 329. 